\title{
The Effect of Networking, Online Sales, Offline Sales, and Training on the Trust of Cooperative Members
}

\author{
Welly Trilaksono ${ }^{1}$, David Sukardi Kodrat ${ }^{2}$ \\ ${ }^{1}$ Biro Perekonomian Provinsi Jatim, ${ }^{2}$ School Of Business and Management, Universitas Ciputra Surabaya \\ gonto.saguh@gmail.com, \\ david.kodrat@ciputra.ac.id \\ https://doi.org/10.37715/rmbe.v1i2.2438
}

\begin{abstract}
This study aims to analyze the effect of networking, online sales, offline sales, and training on the trust of members of the Karya Utama Sejati cooperative. This research is important because optimal member trust can be influenced by Networking, online sales, offline sales, and training at Koperasi Karya Utama Sejati. The sample in this study were all members of the Karya Utama Sejati cooperative, totaling 58 people. The research design used is quantitative research with a descriptive approach with an emphasis on theory testing through measurement of research variables through distributing research questionnaires. The analysis technique in this study is to use multiple linear regression analysis with the help of SPSS 20.0 software. The results showed that the networking variables had an effect on member trust, online sales had an effect on member trust, offline sales had an effect on member trust and training had an effect on the trust of members of the Karya Utama Sejati Cooperative and there was a simultaneous influence on networking, online sales, offline sales and training on trust members of the Karya Utama Sejati cooperative. The advice that can be given to the Karya Utama Sejati cooperative is to improve networking, online sales, offline sales, and training to maximize the trust of cooperative members and achieve the vision and mission of the cooperative.
\end{abstract}

Keywords -Networking, Online Sales, Offline Sales, Training, Member Trust, Koperasi Karya Utama Sejati.

\section{Introduction}

Cooperatives have a function to improve economic and social welfare by developing every potential and economic capacity of its members (Fitriani, 2015). Karya Utama Sejati Cooperative is a Consumer cooperative established on July 15, 2019 with a legal entity number; 014152/BH/M.KUKM.2/VII/2019 consists of business actors, small and medium enterprises where each member has a business to be marketed through cooperatives. Cooperative is a place to accommodate every product from members to help market the products they produce. The problems faced by the Karya Utama Sejati Cooperative in marketing the products of its members are networking, online sales, offline sales, training, trust for Karya Utama Sejati cooperative members. This study aims to determine whether networking, online sales, offline sales, training on the trust of members of the Karya Utama Sejati Cooperative influence each other in improving and developing cooperatives in the field of product sales owned by each member of the cooperative.

\section{Literature Review}

Networking needs to be built in order to expand and increase sales of products produced by cooperative members in expanding the marketing of the products produced. According to research by Toryanto and Hasyim (2017) entitled "Networking Quality and Trust in Professional Service", the company is able to provide certain services according to customer needs and build proximity through a business network is more likely to improve marketing performance.

Product marketing online has been done by placing goods in market places, social media such as Instagram, Facebook have been carried out by cooperative members but have not gotten maximum sales results. Social media allows people to interact freely with other people and offers various ways for marketers to reach and engage with consumers (Voorveld et al., 2018).

Offline marketing through the facilities provided by the facilitator is expected to be able to boost sales because there is interaction between sellers and buyers. Direct negotiations resulting in continuous ordering are the expectations of all cooperative members. According to Chiang and Lin (2018) from research entitled "Measuring 
the effects of online-to-offline marketing", the main reason consumers choose to buy through physical channels is because they can provide better sales service quality and have a lower shopping risk.

Appropriate training for members of the Karya Utama Sejati Cooperative is expected to develop individual abilities so that they can encourage the organization to achieve the desired goals. According to Lolowang et al. (2016) research entitled "Pengaruh pelatihan dan pengembangan sumber daya manusia terhadap kinerja karyawan pada PT. Berlian Kharisma Pasifik Manado", training and development has an important role in improving the performance of each employee to be of higher quality.

Raharjo and Mulyanto (2018) revealed that reputation will affect the value of consumer buying interest in MSME food products directly or indirectly through trust. This includes trust in the product that is owned will build a consumer confidence to buy the resulting product. In addition, Mowen and Minor in (2012, as cited in Priansa, 2017)define trust as a consumer's knowledge and conclusions about objects, attributes, and benefits. Trust is something that relates to the psychological area, where consumers pay attention to receive goods or services based on their expectations of good behavior from others (Rousseau et al., 1998 as cited in Priansa, 2017). According to Maharani (2010), a person's belief in the reliability, durability, and integrity of other people in this relationship is called trust. This action is carried out with the best interests in mind which is of course expected to produce positive results for the trusted party. Meanwhile, according to Pavlo (2002, as cited in Priansa, 2017, p. 116) Trust is a person's assessment of other people who will carry out a transaction in accordance with his expectations even though it is full of uncertainty.

\section{Research Methods 3.1 Analysis Model}

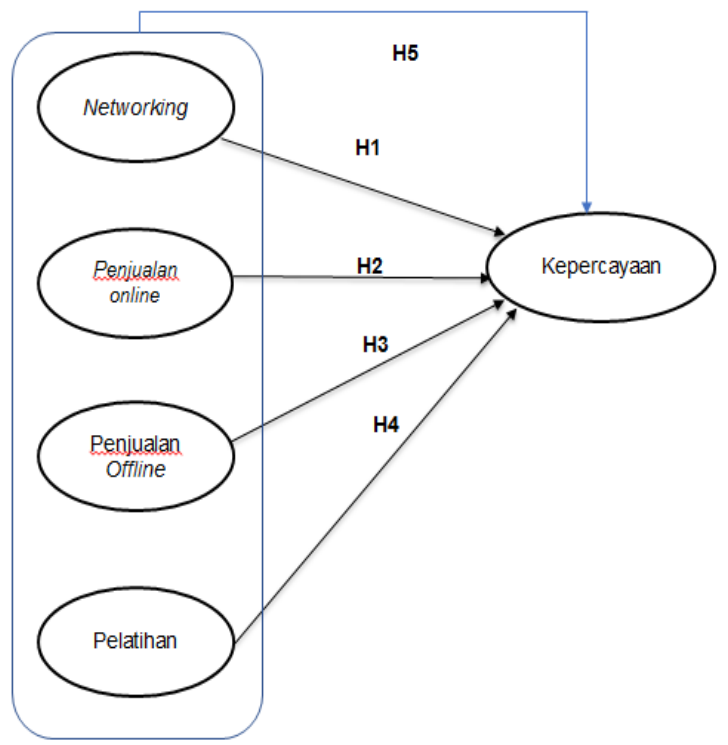

Figure 3.1 Simple Descriptive Research Analysis Procedure Source: Kasim et al. (2020)

Based on previous research and the above theories, the hypotheses of this study are:

H1 : Does Networking have a positive effect on the trust of members of the Karya Utama Sejati Cooperative?

H2 : Does online sales have a positive effect on the trust of members of the Karya Utama Sejati Cooperative?

H3 : Does Offline Sales have a positive effect on the trust of members of the Karya Utama Sejati Cooperative?

H4 : Does the training have a positive effect on the trust of members of the Karya Utama Sejati Cooperative?

H5 : Is there a joint influence of Networking, Online Sales, Offline Sales, and Training on the Trust of Karya Utama Sejati Cooperative Members?

\subsection{Research Approach \& Design}

The population in this study were members of the Karya Utama Sejati Cooperative spread across 17 districts/cities in East Java totaling 58 people, sampling the data using the existing population. The type of data used in this research is quantitative data of interval type. Interval data type is data that is nailed with the distance between two points on a known scale (Kuncoro, 2013). The data in this study were collected using a Likert scale questionnaire. The data used in this study are primary data obtained directly from the source, namely 58 cooperative members, primary data specifically collected by researchers to answer research questions (Indriantoro \& Supomo, 
2002). The primary data used in this study were obtained from questionnaires filled out by members of the Karya Utama Sejati Cooperative through WhatsApp Messenger. The data collection method carried out in this study used a questionnaire technique, namely a data collection by providing or distributing a list of questions/statements to respondents in the hope that respondents would respond to these questions (Umar, 2004). This questionnaire is used to determine the effect of networking, marketplace, offline sales, and training on the trust of cooperative members.

\section{Result and Discussion \\ 4.1 Descriptive statistics}

Table 4.1. Mean Value and Standard Deviation of Networking Variable

\begin{tabular}{|l|r|r|r|}
\hline & \multicolumn{1}{|c|}{ N } & \multicolumn{1}{c|}{ Mean } & \multicolumn{1}{c|}{ Std.Deviasion } \\
\hline X1.1 & 58 & 4,03 & 0,86 \\
\hline $\mathbf{X 1 . 2}$ & 58 & 4 & 0,82 \\
\hline $\mathbf{X 1 . 3}$ & 58 & 3,9 & 0,86 \\
\hline $\mathbf{X 1 . 4}$ & 58 & 4,05 & 0,87 \\
\hline $\mathbf{X 1 . 5}$ & 58 & 3,98 & 0,71 \\
\hline $\mathbf{X}$ & & $\mathbf{4}$ & $\mathbf{0 , 8 2}$ \\
\hline
\end{tabular}

In the table the mean and standard deviation of the networking variable shows the mean value for the networking variable is 4 , followed by the value of the standard deviation of 0.82 , which indicates that the majority of respondents on this variable. The smallest standard deviation of this variable is 0.71 which indicates the most homogeneous of other indicators.

Table 4.2. Mean Value and Standard Deviation of Online Sales Variable

\begin{tabular}{|l|l|r|r|}
\hline & N & Mean & Std. Deviasi \\
\hline X2.1 & 58 & 4,1 & 0,9 \\
\hline $\mathbf{X 2 . 2}$ & 58 & 4,05 & 0,85 \\
\hline $\mathbf{X 2 . 3}$ & 58 & 4,12 & 0,86 \\
\hline $\mathbf{X}$ & & $\mathbf{4 , 0 9}$ & $\mathbf{0 , 8 7}$ \\
\hline
\end{tabular}

In the table the mean and standard deviation of the online sales variable shows the mean value for the variable is 4 followed by the value of the standard deviation of 0.99 which indicates that most of the respondents agree on this variable. The smallest standard deviation of this variable is 0.85 which indicates the most homogeneous of other indicators.

Table 4.3. Mean Value and Standard Deviation of Offline Sales Variable

\begin{tabular}{|r|r|r|r|}
\hline & N & \multicolumn{1}{|l|}{ Mean } & Std. Deviation \\
\hline $\mathbf{X 3 . 1}$ & 58 & 4,1 & 0,83 \\
\hline $\mathbf{X 3 . 2}$ & 58 & 3,95 & 0,8 \\
\hline $\mathbf{X 3 . 3}$ & 58 & 4,1 & 0,74 \\
\hline $\mathbf{X 3 . 4}$ & 58 & 3,91 & 0,8 \\
\hline $\mathbf{X 3 . 5}$ & 58 & 3,9 & 0,83 \\
\hline $\mathbf{X 3 . 6}$ & 58 & 3,93 & 0,88 \\
\hline $\mathbf{X 3 . 7}$ & 58 & 4,02 & 0,91 \\
\hline $\mathbf{X 3 . 8}$ & 58 & 4,07 & 0,97 \\
\hline $\mathbf{X}$ & & $\mathbf{4}$ & $\mathbf{0 , 8 5}$ \\
\hline
\end{tabular}

In the table the mean and standard deviation of the offline sales variable shows the mean value for the offline sales variable is 4 followed by the value of the standard deviation of 0.85 which indicates that most respondents agree on this variable. The smallest standard deviation of this variable is 0.74 which indicates the most homogeneous of other indicators.

Table 4.4. Mean Value and Standard Deviation of Training Variable

\begin{tabular}{|l|r|r|r|}
\hline & N & \multicolumn{1}{|l|}{ Mean } & Std. Deviation \\
\hline X4.1 & 58 & 4,1 & 0,77 \\
\hline $\mathbf{X 4 . 2}$ & 58 & 4,1 & 0,81 \\
\hline $\mathbf{X 4 . 3}$ & 58 & 4,05 & 0,85 \\
\hline $\mathbf{X 4 . 4}$ & 58 & 4,09 & 0,8 \\
\hline $\mathbf{X}$ & & $\mathbf{4 , 0 9}$ & $\mathbf{0 , 8 1}$ \\
\hline
\end{tabular}

The table of mean and standard deviation of the training variable shows the mean value of the training variable of 4.09 followed by the value of the standard deviation of 0.81 which indicates that most of the respondents agree on this variable. The smallest standard deviation of this variable is 0.77 which indicates the most homogeneous of other indicators.

Table 4.5. Mean Value and Standard Deviation of the Confidence Variable

\begin{tabular}{|l|r|r|r|}
\hline & N & \multicolumn{1}{|l|}{ Mean } & Std. Deviation \\
\hline Y1.1 & 58 & 3,98 & 0,69 \\
\hline Y1.2 & 58 & 4,05 & 0,85 \\
\hline Y1.3 & 58 & 4,14 & 0,85 \\
\hline Y & & $\mathbf{4 , 0 6}$ & $\mathbf{0 , 7 9}$ \\
\hline
\end{tabular}




\subsection{Validity and Reliability Test}

\subsubsection{Validity test}

Based on the results of the validity test of all items on the variables of networking, online sales, offline sales, training and trust, the overall results are valid because they have a significant value below 0.05 .

4.2.2. Reliability Test

Table 4.6. Reliability Test Results

\begin{tabular}{|l|l|l|l|}
\multicolumn{1}{|c|}{ Variable } & \multicolumn{1}{c|}{ Cronbach Alpha } & \multicolumn{1}{c|}{ Criteria } & Description \\
\hline Networking (X1) & 0.88 & $\geq 0.60$ & Reliable \\
\hline Online Sales (X2) & 0.866 & $\geq 0.60$ & Reliable \\
\hline Offline Sales (X3) & 0.937 & $\geq 0.60$ & Reliable \\
\hline Training (X4) & 0.887 & $\geq 0.60$ & Reliable \\
\hline Member Trust (Y) & 0.798 & $\geq 0.60$ & Reliable \\
\hline
\end{tabular}

Source: Primary Data Processed, 2021

Based on the Table of Reliability Test Results of research variables, the variables of networking, online sales, offline sales, training and member trust have a Cronbach alpha value of more than 0.60 which means that the overall variable is reliable.

\subsubsection{Multiple Linear Regression Analysis.}

Table 4.7. Regression Equation

\begin{tabular}{|c|c|c|c|c|c|}
\hline \multirow{2}{*}{ Model } & \multicolumn{2}{|c|}{$\begin{array}{c}\text { Unstandardized } \\
\text { Coefficients }\end{array}$} & $\begin{array}{c}\text { Standardized } \\
\text { Coefficients }\end{array}$ & \multirow[t]{2}{*}{$\mathrm{t}$} & \multirow{2}{*}{ Sig. } \\
\hline & B & Std. Error & Beta & & \\
\hline 1 (Constant) & .304 & .273 & & 1.116 & .270 \\
\hline Networking & .087 & .033 & .148 & 2.648 & .011 \\
\hline Online Sales & .216 & .040 & .247 & 5.385 & .000 \\
\hline Offline Sales & .138 & .023 & .388 & 6.132 & .000 \\
\hline Training & .186 & .044 & .257 & 4.209 & .000 \\
\hline
\end{tabular}

Source: Primary Data Processed, 2021

Based on the results of multiple linear regression analysis in table 4.6. the regression equation is obtained as follows:

$$
\mathrm{Y}=0,148(\mathrm{X} 1)+0,247(\mathrm{X} 2)+0,388(\mathrm{X} 3)+0,257(\mathrm{X} 4)
$$

Based on the various parameters in the regression regarding the factors that affect Member Trust, it can be interpreted as follows:

1. The networking regression coefficient obtained is 0.148 which states that if networking increases then member trust will increase and vice versa if networking decreases, the intensity of use will decrease.

2. The regression coefficient of online sales is 0.247 which states that if online sales increase, member trust will also increase and vice versa if online sales decrease, member trust will also decrease.

3. The offline sales regression coefficient is 0.388 which states that if offline sales increase, member trust will also increase and vice versa if offline sales decrease then member trust will also decrease.

4. The regression coefficient for training is 0.257 which states that if the training increases then the trust of members will also increase and vice versa if the training decreases then the trust of members will also decrease.

\subsection{Hypothesis testing}

\subsection{1. $\quad$ t test}

Table 4.8. Parisal test ( $\mathrm{t}$ test)

\begin{tabular}{|c|c|c|c|c|c|}
\hline \multirow{2}{*}{ Model } & \multicolumn{2}{|c|}{$\begin{array}{l}\text { Unstandardized } \\
\text { Coefficients }\end{array}$} & $\begin{array}{l}\text { Standardized } \\
\text { Coefficients }\end{array}$ & \multirow[t]{2}{*}{$\mathrm{t}$} & \multirow{2}{*}{ Sig. } \\
\hline & B & Std. Error & Beta & & \\
\hline 1 (Constant) & .304 & .273 & & 1.116 & .270 \\
\hline Networking & .087 & .033 & .148 & 2.648 & .011 \\
\hline Online Sales & .216 & .040 & .247 & 5.385 & .000 \\
\hline Offline Sales & .138 & .023 & .388 & 6.132 & .000 \\
\hline Training & .186 & .044 & .257 & 4.209 & .000 \\
\hline
\end{tabular}

Source: Primary Data Processed, 2021 
Based on the table the results of the $t$ test can be explained as follows:

a. The Effect of Networking on Member Trust Based on the results of multiple linear regression, it shows that the t value is 2.648 and the significance value is 0.011 , so Networking (X1) has an effect on Member Trust, so that hypothesis 1 is accepted.

b. Effect of Online Sales on Member Trust. Based on the results of multiple linear regression showing a tcount value of 5.385 and a significance value of 0.036 with a smaller significance value $(=0.05)$, Online Sales (X2) has an effect on Member Trust, so that the hypothesis 2 accepted.

c. Effect of Offline Sales on Member Trust. Based on the results of multiple linear regression showing a tcount value of 6.132 and a significance value of 0.000 with a smaller significance value $(=0.05)$, Offline Sales (X3) has an effect on Member Trust, so that hypothesis 3 is accepted.

d. Effect of Training on Member Trust. Based on the results of multiple linear regression showing a t-count value of 4.209 and a significance value of 0.000 with a smaller significance value $(=0.05)$, then Training (X4) has an effect on Member Trust, so that hypothesis 4 is accepted.

\subsubsection{F test}

Table 4.9. $\mathrm{F}$ test

\begin{tabular}{|l|r|r|r|r|r|}
\hline \multicolumn{1}{|c|}{ Model } & $\begin{array}{c}\text { Sum of } \\
\text { Squares }\end{array}$ & df & Mean Square & F & Sig. \\
\hline 1 Regression & 226.325 & 4 & 56.581 & 503.948 & $.000^{a}$ \\
Residual & 5.951 & 53 & .112 & & \\
Total & 232.276 & 57 & & & \\
\hline
\end{tabular}

Source: Primary Data Processed, 2021

From the table above, it is shown that the calculated $\mathrm{F}$ is 503.948 with a significance level of 0.000 . Because the significance value of 0.000 is smaller than 0.05 , then H5 is accepted, meaning that networking, online sales, offline sales, training have a joint effect on member trust.

\subsection{Coefficient of Determination $R^{2}$}

Table 4.10. Coefficient of Determination

\begin{tabular}{|c|c|r|r|r|r|}
\hline Model & R & R Square & $\begin{array}{c}\text { Adjusted R } \\
\text { Square }\end{array}$ & $\begin{array}{c}\text { Std. Error of the } \\
\text { Estimate }\end{array}$ & $\begin{array}{l}\text { Durbin- } \\
\text { Watson }\end{array}$ \\
\hline $\mathbf{1}$ & $\mathbf{. 9 8 7}$ & $\mathbf{. 9 7 4}$ & $\mathbf{. 9 7 2}$ & $\mathbf{. 3 3 5 0 8}$ & $\mathbf{1 . 8 1 2}$ \\
\hline
\end{tabular}

Sumber: Data Primer Diolah, 2021

Based on the table above, it can be seen that the coefficient of determination (R Square) is 0.972 , meaning that $97 \%$ of the variation in member trust can be explained by the three independent variables consisting of Networking (X1), online sales (X2), offline sales (X3) and training (X4). While the remaining $0.3 \%$ is explained by other reasons or influenced by other variables outside the independent variables studied.

\subsection{Classic Assumption Test}

4.5.1. Normality test

Table 4.11. Normality Test with Kolmogorov-Smirnov One-Sample Kolmogorov-Smirnov Test

\begin{tabular}{|ll|l|}
\hline & & Unstandardized Residual \\
\hline $\mathrm{N}$ & & 58 \\
Normal Parameters ${ }^{\mathrm{a}}$ & Mean & .0000000 \\
& Std. Deviation & .32310523 \\
Most Extreme Differences & Absolute & .125 \\
& Positive & .125 \\
& Negative & -.066 \\
Kolmogorov-Smirnov Z & & .952 \\
Asymp. Sig. (2-tailed) & & .325 \\
\hline
\end{tabular}

Source: Primary Data Processed, 2021

Based on the table the data is normally distributed, using Kolmogorov-Smirnov because it uses more than 30 samples. It can be seen in the table where the significant points are 0.325 . This indicates that the data has a normal distribution, as evidenced by the significance value above 0.05 . 


\subsubsection{Multicollinearity Test}

Table 4.12. Multicollinearity Test

\begin{tabular}{|l|r|l|}
\hline \multirow{2}{*}{ Model } & \multicolumn{2}{|l|}{ Collinearity Statistics } \\
\cline { 2 - 3 } & Tolerance & VIF \\
\hline 1 (Constant) & .154 & \\
Networking & 6.482 \\
Online Sales & .231 & 4.336 \\
Offline Sales & .121 & 8.291 \\
Training & .129 & 7.727 \\
\hline Source: Primary Data Processed, 2021
\end{tabular}

In the table results, all independent variables namely networking, online sales, offline sales and training have tolerance points above 0.10 and all VIF points $<10$. So it can be interpreted that VIF points are free from multicollinearity. As a breakdown, the value of VIF on networking $\rightarrow$ member trust $=6,482$, online sales $\rightarrow$ member trust $=4,336$; Offline Sales $\rightarrow$ Member Trust $=8,291$; . Training $\rightarrow$ Member's Trust $=7,272$. So that there is no multicollinearity.

\subsubsection{Heteroscedasticity Test}

Table 4.12. Heteroscedasticity

\begin{tabular}{|c|c|c|c|c|c|}
\hline \multirow[t]{2}{*}{ Model } & \multicolumn{2}{|c|}{$\begin{array}{l}\text { Unstandardized } \\
\text { Coefficients }\end{array}$} & \multirow{2}{*}{$\begin{array}{c}\begin{array}{c}\text { Standardized } \\
\text { Coefficients }\end{array} \\
\text { Beta }\end{array}$} & \multirow[t]{2}{*}{$\mathrm{t}$} & \multirow[b]{2}{*}{ Sig. } \\
\hline & B & Std. Error & & & \\
\hline (Constant) & .608 & .153 & & 3.968 & .000 \\
\hline Networking & .012 & .019 & .202 & .628 & .533 \\
\hline Online Sales & -.021 & .023 & -.242 & -.921 & .361 \\
\hline Offline Sales & -.022 & .013 & -.618 & -1.698 & .095 \\
\hline Training & .022 & .025 & .308 & .877 & .384 \\
\hline
\end{tabular}

Sumber: Primary Data Processed, 2021

The table shows significance points for all independent variables above 0.05 . These data indicate that there is no heteroscedasticity in the research conducted. For details, the significance value of Networking is 0.533 ; the significance value of online sales is 0.361 ; offline sales with a significance value of 0.95 and training with a significance value of 0.384 .

\section{Conclusions and Practical Implication}

Based on the results of the analysis and discussion of the effect of Networking, Online Sales, and Offline Sales on the Trust of Karya Utama Sejati Cooperative Members, it can be concluded that Networking has a positive and significant partial effect on the Trust of Karya Utama Sejati Cooperative Members. Online sales have a positive and significant effect partially on the Trust of Karya Utama Sejati Cooperative Members. Offline sales have a positive and significant partial effect on the Trust of Karya Utama Sejati Cooperative Members. Training has a positive and significant effect partially on the Trust of Karya Utama Sejati Cooperative Members. Networking, Online Sales and Offline Sales together have a positive and significant effect on Member Trust in Mobile Health Applications for Laboratory Examinations on Pramita Lab Surabaya Patients.

Sales through exhibitions are higher than sales in showrooms because the exhibition is a certain event and mostly held in large malls which are visited by many people, customers who are in the area near the exhibition will be contacted by cooperative members via Facebook, Instagram or via Whatapps Messenger by cooperative members who are participating in exhibitions by providing special prices such as providing a condition to buy several products and get certain discounts. Offline sales orders are mostly obtained from exhibitions, after negotiations occur and transactions occur in the form of orders, offline sales through orders are also obtained related to online promotions, most of the order is distributors with product specifications that have been given to cooperative members, product orders can also be established in collaboration with companies that participate in the tender for the procurement of goods with product specifications that have been determined.

\section{References}

Chiang, I.-P., \& Lin, C.-Y. (2018). Measuring the effects of online-to-offline marketing. Contemporary Management Research, 14(3), 167-190. https://doi.org/10.7903/cmr.18462 
Fitriani, F. (2015). Penguatan kapasitas kelembagaan gapoktan melalui pembentukan koperasi pertanian. Masyarakat, Kebudayaan Dan Politik, 28(2), 65-71. https://doi.org/10.20473/mkp.V28I22015.65-71

Indriantoro, N., \& Supomo, B. (2002). Metodologi penelitian bisnis untuk akuntansi dan manajemen. Yogyakarta: BPFE.

Kasim, A., Bungin, B., Dzakiria, H., \& Mokhtar, M. F. (2020). Metode penelitian pariwisata dan Hospitality. Jakarta: Kencana.

Kuncoro, M. (2013). Metode riset untuk bisnis dan ekonomi: Bagaimana meneliti dan menulis tesis? Jakarta: Erlangga.

Lolowang, M. G., Adolfina, A., \& Lumintang, G. (2016). Pengaruh pelatihan dan pengembangan sumber daya manusia terhadap kinerja karyawan pada PT. Berlian Kharisma Pasifik Manado. Jurnal EMBA: Jurnal Riset Ekonomi, Manajemen, Bisnis Dan Akuntansi, 4(2), 177-186.

Maharani, A. D., \& Darmastuti, I. (2010). Analisis pengaruh kepercayaan dan kepuasan terhadap loyalitas nasabah tabungan Bank Mega Semarang. Universitas Diponegoro.

Priansa, D. J. (2017). Komunikasi pemasaran terpadu. Bandung: Pustaka Setia.

Raharjo, R. M., \& Mulyanto, H. (2018). Kualitas produk, citra merek dan minat beli konsumen keripik singkong. Jurnal Manajemen Kewirausahaan, $15(1), \quad 109-120$. https://doi.org/10.33370/jmk.v15i1.198

Toryanto, A. A., \& Hasyim. (2017). Networking quality and trust in professional services. European Research Studies Journal, XX(3A), 354-370. https://doi.org/10.35808/ersj/714

Umar, H. (2004). Metode Riset Ilmu Administrasi. Jakarta: Gramedia Pustaka Utama.

Voorveld, H. A. M., van Noort, G., Muntinga, D. G., \& Bronner, F. (2018). Engagement with social media and social media advertising: The differentiating role of platform type. Journal of Advertising, 47(1), 38-54. https://doi.org/10.1080/00913367.2017.1405754 